\title{
DISAIN PENELITIAN STRATEGI INISIATIF PENINGKATAN KINERJA PERUSAHAAN MENGGUNAKAN BALANCED SCORECARD
}

\author{
Oleh: \\ R. Adam Maulana Rizaldy ${ }^{1)}$, Baltasar Asa ${ }^{1)}$ \\ E-mail:Morisfoun261@yahoo.com \\ ${ }^{1)}$ Mahasiswa Magister Manajemen Fakultas Ekonomi Universitas Narotama
}

\begin{abstract}
Penerapan balanced scorecard di PT. XYZ belum berjalan dengan maksimal. Ada beberapa indikator kinerja utama yang mengalami perubahan baik target, bobot atau metode evaluasi. Beberapa indikator kinerja utama dinilai kurang relevan dengan departemen terkait, target terlalu rendah atau terlalu tinggi. Proses validasi atas indikator kinerja utama sedikit mengalami hambatan karena banyak data yang diragukan kebenarannya. Pada tahun 2015, penerapan balanced scorecard di PT. XYZ semakin lancar setelah dilakukan proses perubahan dan perbaikan indikator kinerja utama pada akhir tahun 2014 serta dilakukan penandatanganan balanced scorecard yang baku oleh direksi Presiden Direksi PT. XYZ.Setelah dilakukan penerapan balanced scorecar maka diketahui strategi inisiatif perusahaan untuk meningkatkan kinerja perusahaan adalah employee capabilities, information systems capabilities, serta motivation, empoverment, and aligment.
\end{abstract}

Keywords. balanced scorecard, indikator kinerja utama,strategi inisiatif

\section{PENDAHULUAN}

PT. XYZ adalah sebuah perusahaan keluarga yang bergerak dibidang produksi kertas industri dan kimia yang berdiri sejak tahun 1977 dan memiliki kurang lebih $\square \square \square \square$ orang karyawan, berlokasi di Mojokerto. Produksi kertas yang diproduksi antara lain adalah Coated Duplex dan Manila, Kraft Liner dan Test Liner, Corrugating Medium, Chip Board, sedangkan untuk kimia antara lain adalah $\mathrm{NaOH}, \mathrm{HCl}$, dan Hypo.

Sejak awal tahun 2013, PT. XYZ mulai menerapkan balanced scorecard. Proses perancangan balanced scorecard yang sudah dilaksanakan pada tahun itu adalah penetapan peta strategi, indikator kinerja utama, target indikator kinerja utama, bobot indikator kinerja utama, periode penilaian indikator kinerja utama dan metode evaluasi untuk masing-masing indikator kinerja utama.

Sampai dengan tahun 2014, penerapan balanced scorecard di PT. XYZ belum berjalan dengan maksimal. Ada beberapa indikator kinerja utama yang mengalami perubahan baik target, bobot atau metode evaluasi. Beberapa indikator kinerja utama dinilai kurang relevan dengan departemen terkait, target terlalu rendah atau terlalu tinggi. Proses validasi atas indikator kinerja utama sedikit mengalami hambatan karena banyak data yang diragukan kebenarannya. Pada tahun 2015, penerapan balanced scorecard di PT. XYZ semakin lancar 
setelah dilakukan proses perubahan dan perbaikan indikator kinerja utama pada akhir tahun 2014 serta dilakukan penandatanganan balanced scorecard yang baku oleh direksi Presiden Direksi PT. XYZ.

Adapun PT. XYZ dipilih sebagai lokasi penelitian karena PT. XYZ merupakan tempat peneliti bekerja sebagai staff Key Performance Indicator selama lebih kurang 3 tahun, hingga saat ini. Peneliti juga bertujuan untuk mengetahui seberapa besar kontribusi penerapan BSC terhadap kinerja perusahaan serta membantu PT. XYZ dalam memperbaiki dan mengembangkan balanced scorecard yang telah diterapkan, sehingga dapat berjalan dengan maksimal. Tujuan yang hendak dicapai melalui penelitian ini adalah untuk; Menganalisis sejauh mana kontribusi Balanced Scorecard dapat diterapkan terutama peranannya dalam meningkatkan kinerja perusahaan pada PT. XYZ. Merancang model pengukuran kinerja bisnis perusahaan berdasarkan pendekatan Balanced Scorecard, dengan menggunakan empat perspektif; keuangan, pelanggan, proses bisnis internal dan proses pembelajaran dan pertumbuhan. Dan mengamati strategi inisiatif masing-masing perspektif Balanced Scorecard untuk meningkatkan kinerja perusahaan.

\section{KERANGKA TEORI}

Kinerja adalah suatu tampilan keadaan secara utuh atas perusahaan selama periode waktu tertentu, merupakan hasil atau prestasi yang dipengaruhi oleh kegiatan operasional perusahaan dalam memanfaatkan sumber-sumber daya yang dimiliki (Helfert, 1996 dalam Srimindarti, 2004). Menurut (Mulyadi B.S, 2001), kinerja adalah istilah umum yang digunakan untuk menunjukkan sebagian atau seluruh tindakan atau aktivitas dari suatu organisasi pada suatu periode. Pengembangan kinerja juga bisa dilakukan dengan menciptakan kepemimpinan yang efektif sehingga pengukuran kinerja dapat dlakukan dengan baik(Alimudin, A., Septian, D., Sasono, A. D., \& Wulandari, 2017).

Berdasarkan pengertian di atas dapat disimpulkan bahwa pengukuran kinerja adalah tindakan pengukuran yang dapat dilakukan terhadap berbagai aktifitas dalam rantai nilai yang ada pada perusahaan(Alimudin \& Sukoco, 2017). Hasil pengukuran tersebut kemudian digunakan sebagai umpan balik yang akan memberikan informasi tentang prestasi pelaksanaan suatu rencana dan titik di mana perusahaan memerlukan penyesuaian atas aktivitas perencanaan dan pengendalian tersebut(Alimudin, 2015). Pengukuran kinerja yang hanya berdasarkan pada kemampuan finansial sudah kurang cocok di tengah pesatnya kemajuan teknologi informasi. Pergeseran paradigma tersebut tentunya juga mengubah acuan yang dipakai untuk mengukur kinerja sebuah perusahaan. Alat ukur kinerja tradisional yang memfokuskan pada pengukuran finansial tentunya harus bergeser dengan pengukuran kinerja non- finansial, seperti kepuasan pelanggan, inovasi produk/jasa, pengembangan perusahaan dan karyawan yang mempunyai rasa memiliki terhadap perusahaan. Balanced Scorecard (BSC) menawarkan cara baru pengukuran kerja yang kompetitif. BSC merupakan sebuah sistem instrumentasi bagi pelaku usaha untuk mengendalikan organisasi perusahaan guna mentranslasikan visi dan misi perusahaan ke dalam bentuk kerangka pengukuran strategis terhadap sekumpulan parameter didalam masing-masing perspektif yang komprehensif, sehingga dapat meningkatkan kemampuan kerja perusahaan guna menciptakan daya saing yang berkelanjutan (sustainable competitive advantage) dalam kondisi persaingan yang kompentitif dewasa ini. Berdasarkan hal tersebut perusahaan perlu menerapkan sebuah model pengukuran kinerja yang komprehensif berdasarkan Balanced Scorecard serta memerlukan 
pembuktian seberapa besar kontribusi penerapan BSC tersebut terhadap kinerja perusahaan(Alimudin, 2017).

Menurut (Kaplan \& Norton, 1996) balanced scorecard tetap mempertahankan ukuran finansial sebagai suatu ringkasan penting kinerja manajerial dan bisnis. Laporan keuangan yang terdiri dari neraca, laporan laba rugi, laporan perubahan modal/ ekuitas, serta laporan arus kas tetap memegang peranan penting dimana informasi yang disediakan bersifat kuantitatif sehingga dapat selalu mengingatkan manajer untuk mengadakan tindakan perbaikan di sektor-sektor yang penting. Keuangan selalu berhubungan dengan kemampuan perusahaan dalam menciptakan harga yang menguntungkan dan diterima oleh konsumen(Alimudin, Simangunsong, Barid, \& Wajdi, 2017)

Perspektif Proses Bisnis Internal memiliki tujuan dan ukuran yang diterjemahkan dari strategi dan ditujukan untuk memenuhi harapan para pemegang saham serta pelanggan. Tujuan dan ukuran ini umumnya dikembangkan setelah tujuan dan ukuran dalam perspektif keuangan dan pelanggan dirumuskan. Dalam hal ini manajemen mengidentifikasi proses bisnis internal yang kritis yang bisa diandalkan oleh perusahaan(Kaplan \& Norton, 1996).

Seberapa baik perusahaan telah menjalankan bisnisnya serta apakah produk dan jasa yang ditawarkan telah sesuai dengan keinginan pelanggan, dapat dilihat dari scorecard yang dibuat, dalam perspektif ini. Oleh karena itu, pendesainan perspektif ini penting dilakukan oleh mereka yang mengetahui secara mendalam atas misi perusahaan dan bukan dari konsultan dari luar(Alimudin, 2013).

Pelanggan cenderung akan berpindah dan mencari produsen atau supplier lain jika kepuasannya tidak terpenuhi(Alimudin, A., \& Artaya, 2009). Oleh karena itu kinerja yang baik dari perspektif ini sangat perlu di tingkatkan. Jika kinerjanya buruk, bukan tidak mungkin, perusahaan akan kehilangan pelanggan dimasa depan walaupun kinerja keuangan saat ini terlihat baik. Produk dan jasa yang bernilai tinggi bagi pelanggan harus diciptakan untuk mencapai kinerja jangka panjang yang baik(Alimudin, Dhaniarti, Judana, \& Sukoco, 2017).

Pengetahuan, kemampuan dan keahlian yang dimiliki oleh manajer dan karyawan merupakan intangible resource/ assets perusahaan. Harta perusahaan ini tidak bisa dinilai dengan uang, tetapi merupakan faktor pendorong yang penting dalam mencapai kinerja keuangan yang mengagumkan, kinerja dalam proses bisnis internal yang baik serta kinerja yang memuaskan dalam perspektif pelanggan perusahaan. Dengan kata lain tujuan perspektif pembelajaran dan pertumbuhan adalah menyediakan infrastruktur (para pekerja, sistem dan prosedur) sebagai pendorong yang memungkinkan tujuan dan kinerja yang istimewa dalam tiga perspektif sebelumnya dapat tercapai(Alimudin, 2015).

\section{METODE PENELITIAN}

Berdasarkan masalah yang diteliti dan teori tersebut diatas, teknik dan alat yang digunakan maka pendekatan yang digunakan pada penelitian ini adalah deskriptif kuantitatif, data yang diperoleh dari sampel populasi penelitian dianalisis sesuai dengan metode statistik yang digunakan kemudian diinterprestasikan. Menurut (Bungin, 2001) metode penelitian ini 
bertujuan untuk mengambarkan, meringkaskan berbagai kondisi, berbagai situasi atau berbagai variabel yang timbul di PT. XYZ yang menjadi objek penelitian tersebut.

Untuk mendapatkan sampel yang representatif terhadap populasi dan dapat menjelaskan karakteristik dari populasi (presisi), maka dilakukan empat langkah pengambilan sampel dalam penelitian, yaitu :

a) Mengidentifikasi target populasi, yaitu menentukan populasi spesifik yang relevan dengan tujuan dan masalah penelitian sebagai dasar pengambilan sampel. Target populasi adalah para pegawai yang ada dilingkungan PT. XYZ sebanyak 194 pegawai dengan level jabatan mulai dari Koordinator, Kabag, Wakabag, Kasi, Wakasi, dan Staff.

b) Menentukan metode pemilihan sampel. Pengambilan sampel dilakukan secara acak (probability/random sampling).

c) Menentukan prosedur penentuan unit sampel. Pemilihan sampel berdasarkan kerangka sampel dilakukan melalui prosedur satu tahap yaitu para pegawai yang ada dilingkungan PT. XYZ, dimana pengumpulan data dilakukan sekaligus atau satu tahap melalui metode survei. Setelah itu peneliti tidak melakukan survei lagi terhadap responden yang sama.

d) Menentukan ukuran sampel. Hal ini penting untuk analisa statistik terhadap data. Penentuan jumlah sampel digunakan teknik pengambilan sampel Stratified Random Sampling atau Sampel Acak Distratifikasikan. Jumlah sampel dalam setiap populasi/stratum ditentukan secara tidak proposional karena jumlah unsur atau elemen di salah satu atau beberapa populasi/stratum sangat sedikit. Rasio jumlah sampel yang merepresentasikan populasi adalah sebagai berikut:

Tabel 1 Rasio Jumlah Sampel

\begin{tabular}{|l|l|}
\hline \multicolumn{1}{|c|}{ Level Jabatan } & \multicolumn{1}{c|}{ Jumlah Sampel } \\
\hline Koordinator & 5 orang \\
\hline Kabag & 3 orang \\
\hline Wakabag & 16 orang \\
\hline Kasi & 23 orang \\
\hline Wakasi & 22 orang \\
\hline
\end{tabular}




\begin{tabular}{|l|l|}
\hline Staff & 31 orang \\
\hline Total & 100 orang \\
\hline
\end{tabular}

Instrumen penelitian merupakan alat untuk mengukur variabel yang diteliti, dimana jumlah instrumen tergantung pada jumlah variabelnya. Instrumen dalam penelitian ini menggunakan skala Likert untuk mengukur setiap pernyataan yang ada pada kuesioner perspektif keuangan, pelanggan, proses bisnis internal, pembelajaran dan pertumbuhan serta kinerja perusahaan. Setiap jawaban dihubungkan dengan bentuk pernyataan atau dukungan sikap yang diungkapkan dengan kata-kata sebagai berikut:

$\begin{array}{llll}\text { Sangat Setuju } & (\mathrm{SS}) & =5 \\ \text { Setuju } & (\mathrm{S}) & = & 4 \\ \text { Kurang Setuju } & (\mathrm{KS}) & = & 3 \\ \text { Tidak Setuju } & (\mathrm{TS}) & = & 2 \\ \text { Sangat Tidak Setuju (STS) } & = & 1\end{array}$

Selain daripada itu dalam penelitian ini juga menggunakan skala rating untuk mengukur urutan (prioritas) terpenting menurut responden terhadap peningkatan kinerja perusahaan. 


\section{DAFTAR PUSTAKA}

Alimudin, A., \& Artaya, I. P. (2009). Persepsi Nasabah Tentang Ketanggapan, Keramahan, Kehandalan, Komunikasi, Dan Mengerti Nasabah Terhadap Pelayanan Bagian Prioritas PT. Bank Central Asia Surabaya. Bisnis Dan Manajemen, 1(2).

Alimudin, A., Septian, D., Sasono, A. D., \& Wulandari, A. (2017). Effect of Spiritual Leadership to Organizational Culture a nd Employee' s Loyalty. Jurnal Terapan Manajemen Dan Bisnis, 3(2), 76-86.

Alimudin, A. (2013). Pengaruh Orientasi Wirausaha Terhadap Keunggulan Bersaing Berkelanjutan Dan Kinerja Pemasaran Usaha Kecil Sektor Perdagangan (Consumer Goods) Di Kota Surabaya. Sustainable Competitive Advantage (SCA), 3(1).

Alimudin, A. (2015). Strategi pengembangan minat wirausaha melalui proses pembelajaran. E-Jurnal Manajemen KINERJA, 1(1).

Alimudin, A. (2017). ANALISIS PENCAPAIAN STRATEGI MENGGUNAKAN BALANCED SCORECARD. Jurnal Pendidikan Ekonomi \& Bisnis (Edisi Elektronik), 5(2), 178-194.

Alimudin, A., Dhaniarti, I., Judana, M. L., \& Sukoco, A. (2017). Model of Customer Value Approach for Improving Satisfaction of the Hospital Patients. SINERGI, 7(2), 30-40.

Alimudin, A., Simangunsong, P., Barid, M., \& Wajdi, N. (2017). The Factors Affecting Land Prices In Housing Location In Sidoarjo Regency. THE SPIRIT OF SOCIETY JOURNAL, 1(1), 37-47.

Alimudin, A., \& Sukoco, A. (2017). The Leadership Style Model That Builds Work Behavior Through Organizational Culture. LENTERA, 3(September).

Kaplan, R. S., \& Norton, D. P. (1996). The Balanced Scorecard Translating Strategy In Action (Kaplan \& Norton, 1996, Harvard Business School Press).pdf. Proceedings of the IEEE. https://doi.org/10.1109/JPROC.1997.628729

Kaplan, Robert S. dan David P. Norton, The Balanced Scorecard: Translating Strategy Into Action, Harvard Business School Press Boston, Massachusetts, 2000

Bungin, B. (2001). Metodologi Penelitian Kualitatif: Aktualisasi Metodologis ke Arah Ragam Varian Kontemporer. Jakarta: Grafindo.

Mulyadi, B. S. (2001). Alat Manajemen Kontemporer untuk Pelipatgandaan Kinerja Keuangan Perusahaan. Jakarta: Salemba Empat. 